\title{
南九十九里浜一宮海岸の長期汀線変化と沿岸漂 砂量分布の推定 \\ LONG-TERM SHORELINE CHANGES AND ESTIMATION OF LONGSHORE SAND TRANSPORT ON ICHINOMIYA COAST
}

\author{
宇多高明 1 ・熊田貴之 2 ・清水達也 3 ・中山拓也 4 ・石井光男 5 ・保田英明 6 \\ Takaaki UDA, Takayuki KUMADA, Tatsuya SHIMIZU, Takuya NAKAYAMA, \\ Mitsuo ISHII and Hideaki YASUDA \\ 1正会員 工博（財）土木研究センター常務理事なぎさ総合研究室長兼 \\ 日本大学客員教授理工学部海洋建築工学科（†110-0016 東京都台東区台東1-6-4タカラビル）

$$
\begin{gathered}
2 \text { 正会員 博 }(\text { 工）（財）土木研究センターなぎさ総合研究室 } \\
\text { （１10-0016 東京都台東区台東1-6-4タカラビル） }
\end{gathered}
$$$$
3 \text { 正会員 修（工）（有）アイコムネット環境コンサルティング部 }
$$$$
\text { （干135-0064 東京都江東区青海2-7-4-627） }
$$ \\ 4 千葉県県土整備部河川整備課海岸砂防室長（干260-8667 千葉市中央区市場町1-1） \\ 5 千葉県県土整備部河川整備課海岸砂防室副主幹（干260-8667 千葉県千葉市中央区市場町1-1） \\ 6 千葉県県土整備部河川整備課海岸砂防室副主査（†260-8667 千葉県千葉市中央区市場町1-1）
}

\begin{abstract}
Ten artificial headlands was constructed on the Ichinomiya coast located in the south part of Kujukuri Beach facing the Pacific Ocean to control northward predominant longshore sand transport. However, the south breakwater of Taito fishing port was also constructed during the same period. This resulted in the formation of wave shelter zone, inducing southward longshore sand transport. Thus, the direction of longshore sand transport entirely changed on this coast. Presently artificial headlands are useful for controlling southward longshore sand transport to prevent sand deposition in the fishing port.
\end{abstract}

Key Words : Artificial headland, Ichinomiya coast, Kujukuri Beach, longshore sand transport, wave shelter zone

\section{1. まえがき}

九十九里浜は, 房総半島東部において太平洋と接 し，北端の屏風ヶ浦から南端の太東崎まで伸びる長 さ約 $60 \mathrm{~km}$ 砂浜海岸であり，未固結の砂岩・泥岩で 構成された屏風ヶ浦と太東崎の海食崖からの崩落土 砂，および太東崎の南側に流入する夷隅川からの流 出土砂が沿岸漂砂によって運ばれた砂が堆積してで きた海岸である. 海浜は細砂から構成されているた め緩勾配の海浜が形成されている。この海岸では, 1970年代以降進められた海食崖の侵食防止工事，九 十九里浜の北端・南端に造られた飯岡・太東漁港に よる沿岸漂砂の阻止などにより供給土砂量が激減し た結果，近年では弧状海岸線の両端部から中央部へ と侵食が進んできている1２）。このため九十九里浜 南部に位置する一宮海岸では，1988年より10基の ヘッドランド（HL）の建設が進められてきた。 HL は, 太東崎方面からの沿岸漂砂の供給量が激減した
中で，減少した沿岸漂砂に見合うようHLによって 波の入射方向と海岸線とのなす角度を減じようとす る目的のもとで1980年代に計画され，1988年以降段 階的に建設工事が進められてきた。このようにHL は北向きの沿岸漂砂を制御することを目的として建 設が進められてきたが，同じ期間に太東崎の付け根 には太東漁港の防波堤が伸ばされたことから，それ による波の遮蔽効果が無視できない可能性が高い. しかし従来の研究1）2）ではこの点が十分検討されて いなかった。 そこで過去の空中写真による汀線変化 分析などを行い，太東漁港の防波堤の建設により一 宮海岸では沿岸漂砂の方向が反転したことを明らか にする。

\section{2. 一宮海岸の長期的変遷}

九十九里浜南端部に位置する一宮海岸では近年侵 


\section{(a) 1947年}

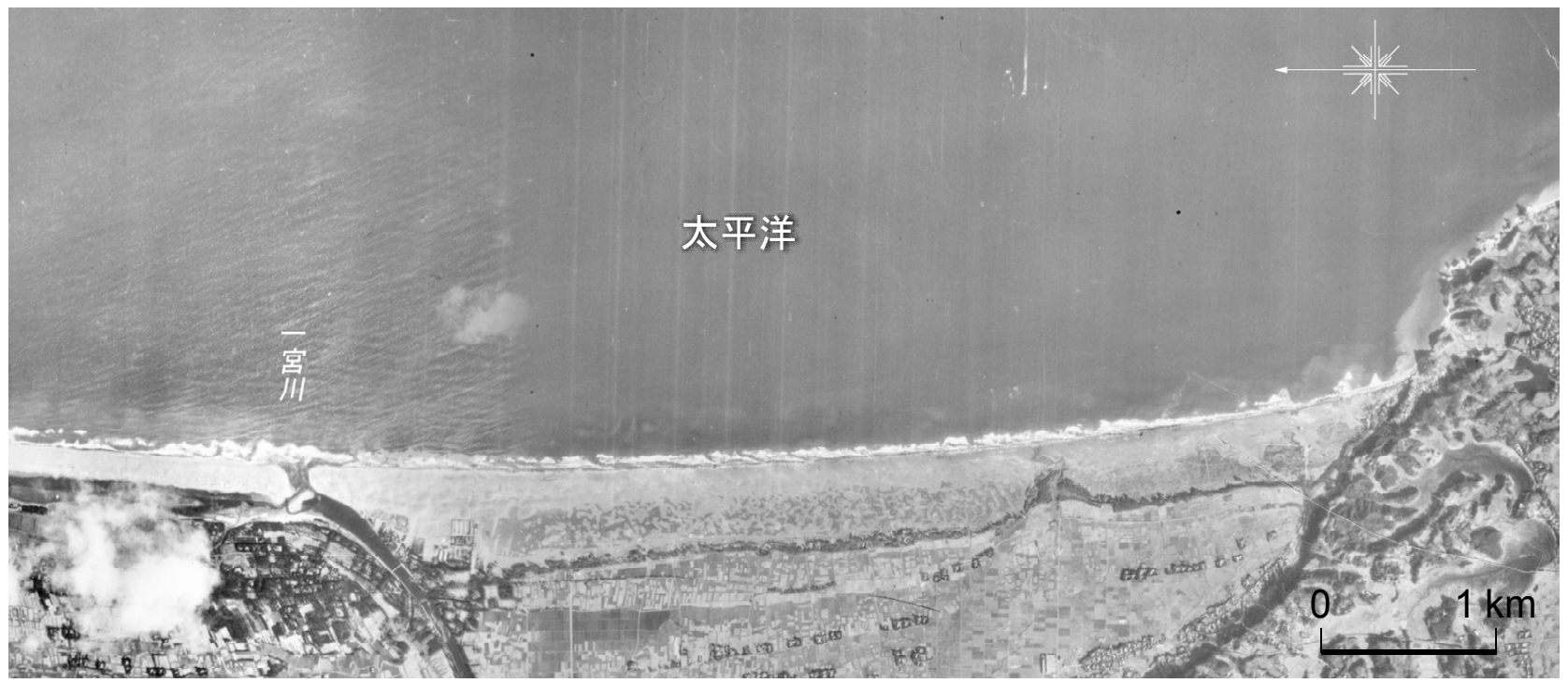

(b) 2010年

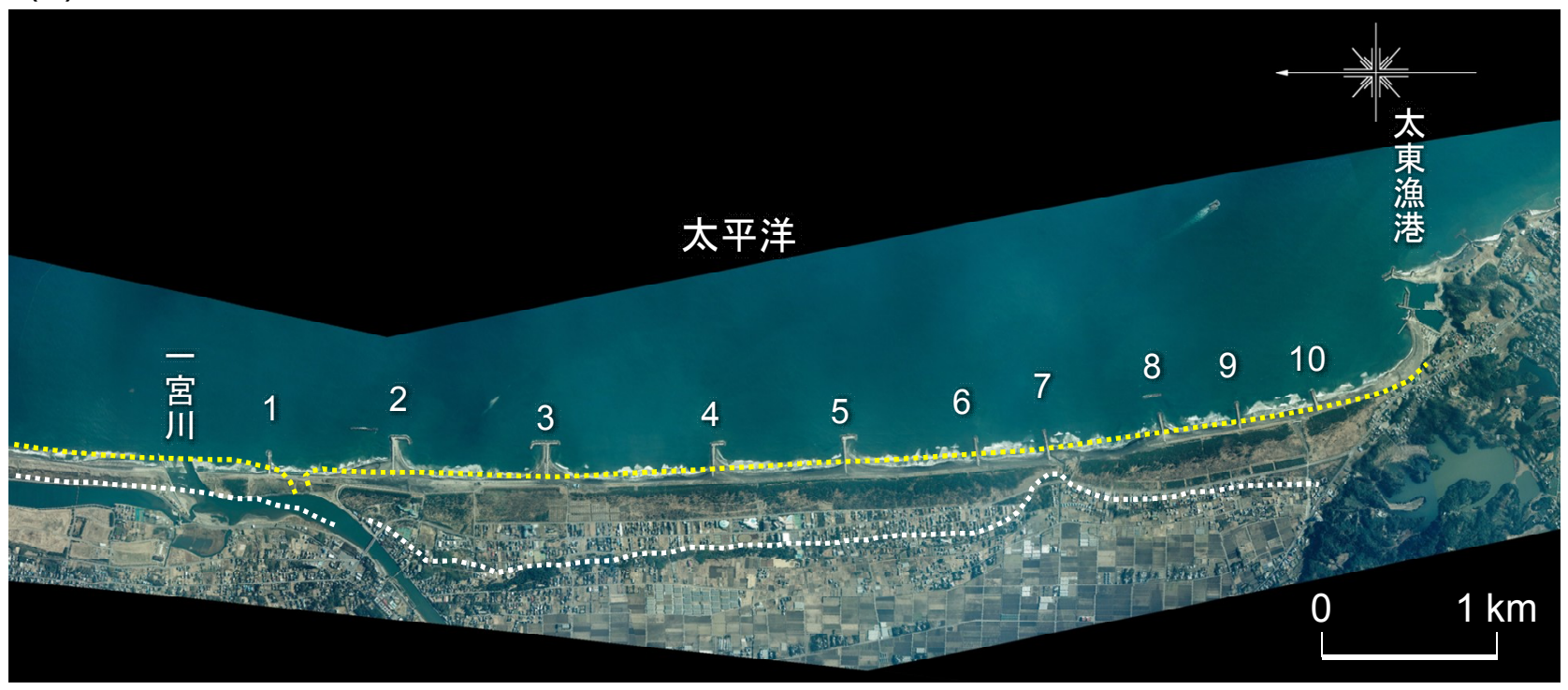

図-1 一宮海岸の1947年と2010年の空中写真

食が著しい。しかしながら侵食の結果汀線が大きく 後退して陸地が失われ海浜が狭まったか，あるいは 陸域での土地利用の変化に伴い, 利用済み空間が海 側へと前進し, 自然砂丘地が狭められて海浜が狭 まったかは現況の海岸を観察したのみでは分からな い.いずれの場合も海浜地が狭まる点においては同 一の結果ではあるが，その意味するところは大きく 異なる。海浜の幅は汀線と利用済み空間の海側境界 線の差として定義されるがゆえにこのような現象が 起こる.この点を一宮海岸について調べるために, 最も古い時期の空中写真として1947年を, また最新 の空中写真として2010年の空中写真を選んで比較し た（図-1参照）。

1947年には海岸線近傍には最大約600m幅の自然砂 丘地が広がっていた（図-1a）。しかし2010年にな
ると，市街地と保安林区域が海側に大きく前進した （図-1b）。図-1bには1947年の自然砂丘地と背後地 との境界線，および汀線をそれぞれ破線で示す.

HL2号から6号間に典型的に見られるように，1947 年当時原野であった自然砂丘地のほぼ $1 / 2$ は2010年 には市街地に変わり, またその海側には保安林区域 が形成され，海浜地がごくわずかになった。一方， 1947年と比較すると, 汀線は太東漁港の北側区域で は局所的に前進しているが，大部分の区域では後退 傾向を示す。しかしその量は自然砂丘地が市街地お よび保安林区域に変わった区域の幅と比較すれば大 きくはない。このように一宮海岸では侵食は進んだ ものの, 人為的改変に伴う背後地の利用空間の広が りのほうがはるかに大きいものであった。 


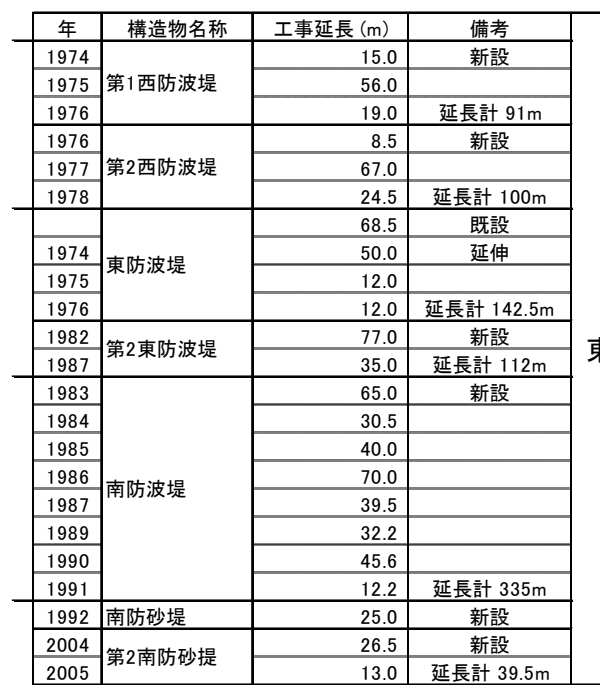

図-2 太東漁港の防波堤の建設経緯

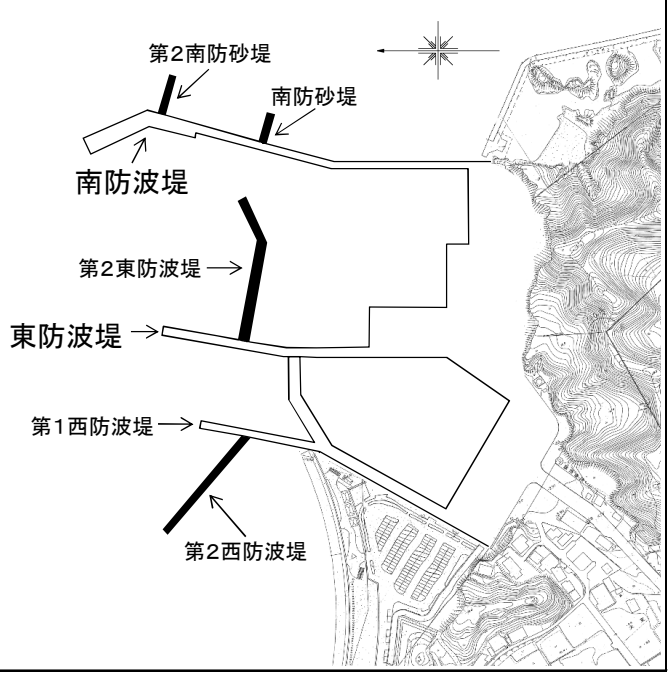

\section{3. 汀線の長期的変化}

\section{（1）太東漁港の建設経緯}

一宮海岸における汀線の長期的変化については, 1947 年撮影の空中写真を初回とし, その後 1980, 2000，2010年の3時期を選んでこの間の汀線変化を 調べた。太東岬の海食崖の侵食防止のために海食崖 基部に消波堤が設置されたのが1975年からであり， これにより沿岸漂砂の供給量が減少したと考えられ ることから1980年を選定した。その後，侵食の激化 とともに1988年からHLによる対策が始まった。そ こでHLの工事開始後 12 年の 2000 年，および2010年 の空中写真を選定した. なお対象区域での汀線変化 に大きな影響をもたらす太東漁港の防波堤の建設経 緯は図-2に示すようである。第1西・東防波堤の建 設は1974年より始まり，また第2西防波堤の建設が 1976年から始まった。海岸線からの突出量の大きい 南防波堤は1983年から1991年の8年間で北向きに $335 \mathrm{~m}$ 伸ばされた. 南防波堤は他の防波堤と比べて海 岸線からの突出長が大きかったために, その北西側 に大きな波の遮蔽域を形成することになった。また HLによる侵食対策工事が始まった時期（1988年） と，南防波堤の完成時期（1991年）とがほぼ同一で あることが注目される。海岸には両者の影響が同時 に現れると考えられるからである.なおこの種の解 析では，汀線変化を示す時期が多すぎると各測定年 の区別ができず，長期の汀線変化傾向を見失う恐れ が高いため, ここでは数10年間の変化を示す意味で 代表的と考えられる4時期の汀線を選定した。

\section{(2) 汀線変化}

図-3には1947年を基準として1980，2000，2010年 までの汀線変化を示す. 図には 10 基のHLの配置も 示す. 1980年までの汀線変化では, 太東漁港のごく 近傍では汀線が大きく前進したが，その北側の $\mathrm{X}=3.5 \mathrm{~km}$ から $\mathrm{X}=7 \mathrm{~km} の 3.5 \mathrm{~km}$ 区間では著しく侵食が

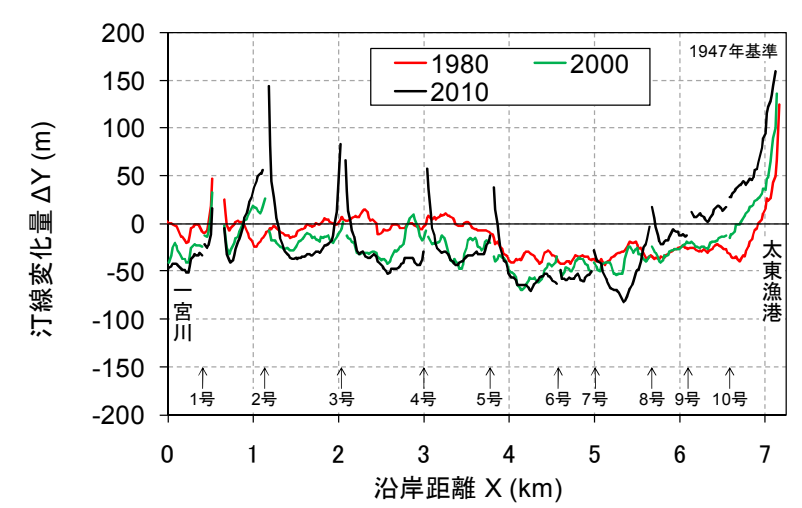

図-3 1947年を基準とした1980，2000，2010年までの汀 線変化

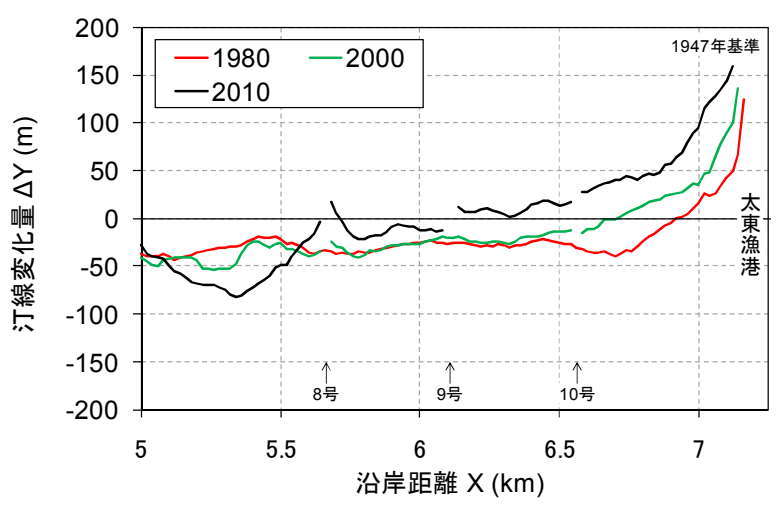

図-4 太東漁港周辺の汀線変化の拡大図

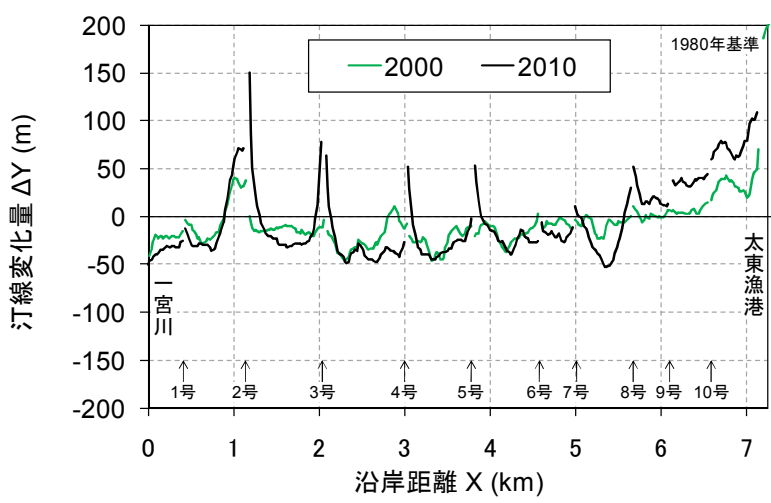

図-5 1980年基準での2000年と2010年までの汀線変化 
(a) 2004年

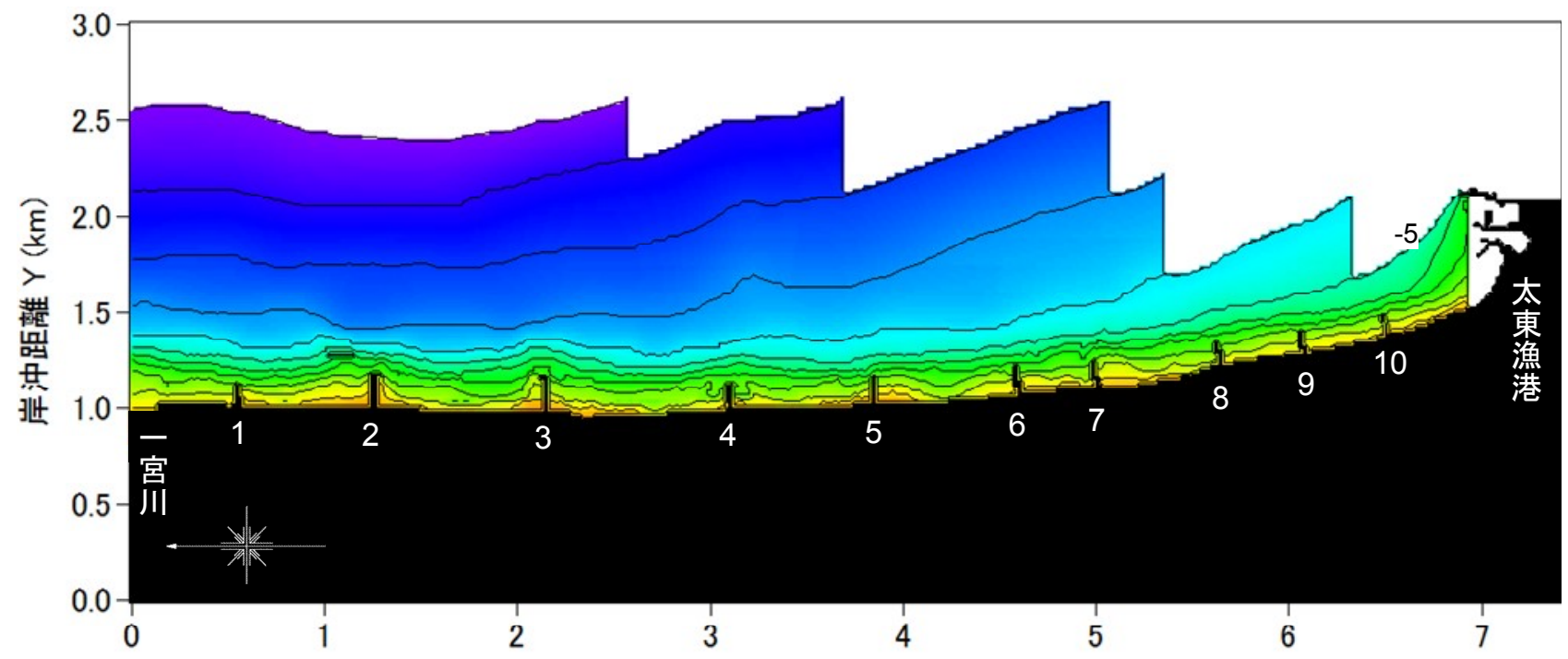

(b) 2010 年

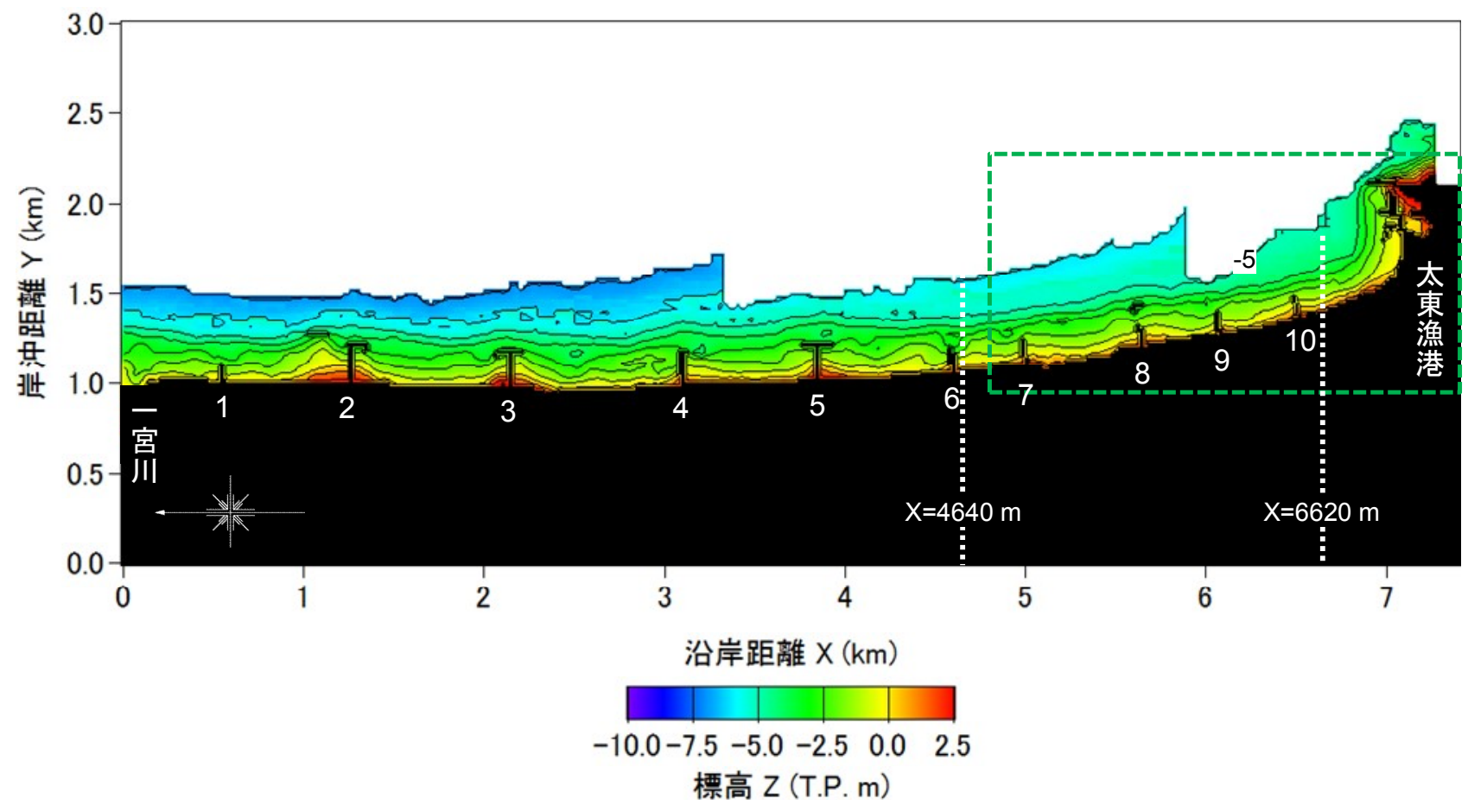

図-6 2004年と2010年における一宮海岸の深浅図

進み， $\mathrm{X}=5.1 \mathrm{~km}$ では汀線が最大 $42 \mathrm{~m}$ 後退した。こ のような太東漁港の北側での汀線の著しい後退状況 より，1980年当時は北向きの沿岸漂砂の供給量の激 減によって侵食域が漁港の北側へと広がったことが 分かる。またこうした状況を受けて海浜の安定化を 図るために1980年代にはHLの計画が進められた。 その後, 太東漁港の防波堤が1991年までに伸ばされ ると, 汀線の変化パターンに大きな変化が現れた。 すなわち2000年までの汀線変化にあっては，1980年 には汀線後退が著しかった太東漁港近傍では，一度 は後退した汀線が再び前進した。これに対してX=2 〜 $5 \mathrm{~km}$ 区間では侵食傾向となった。1990年以降HLの
建設が本格化すると, HL周辺でのスパイク状の汀 線前進が見られたものの，HL間では依然として侵 食傾向が続いた。これらの汀線変化と全く独立に, 太東漁港の北側隣接部の $\mathrm{X}=5.5 \mathrm{~km}$ 以南では汀線前進 が著しい。汀線前進区域が北側に広がらず $X=5.5 \mathrm{~km}$ 以南に留まっていることは, 防波堤による波の遮蔽 効果がこの付近まで及び，北側隣接域から漂砂が逆 流して防波堤遮蔽域へと入り込んでいることを示す と考えられる。図-4は，X=5km（HL7号堤）以南の 区域の汀線変化を拡大して示すが, 太東漁港の北側 隣接部に広い砂浜が形成されたことが明らかである。 $\mathrm{X}=6.5 \mathrm{~km}$ 以南で広がった海浜は夏季には太東漁港海 


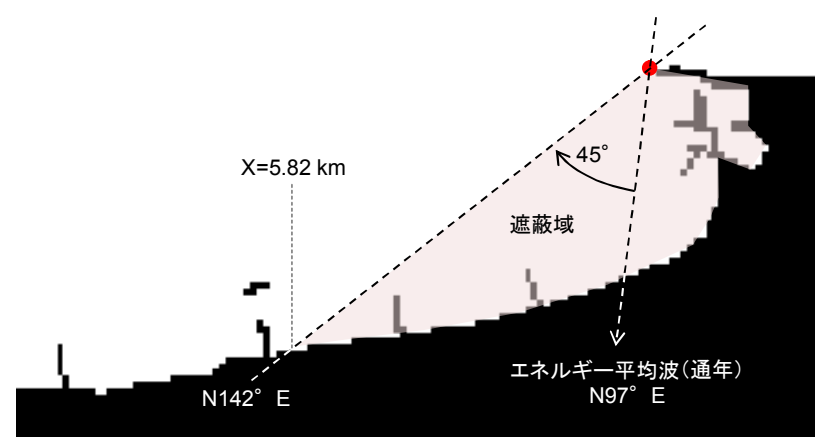

図-7 太東漁港の南防波堤の造る波の遮蔽域

水浴場として多くの人々に利用されている.

1980年以降の汀線変化を詳しく把握するために,

図-5には1980年基準での2000年と2010年までの汀線 変化を示す。太東漁港の防波堤は1991年までに完成 したことから，防波堤による影響を明確な形で把握 することができる.これによればX $=5.5 \mathrm{~km}$ 以南，す なわち $8,9,10$ 号堤付近では時間経過とともに汀線が 前進し，8号堤から太東漁港までの1.5km区間におい て平均で2000年までに $18 \mathrm{~m} ， 2010$ 年までに $47 \mathrm{~m}$ 汀線が 前進したことが明らかである。この汀線変化のみか ら波の遮蔽域に堆積した砂がどこから運び込まれた かを判断することはできないが，北側にはHL群が 伸びており, 沿岸漂砂の移動はかなり抑止される一 方，HL間では侵食傾向にあること，太東漁港の防 波堤南側海浜は近年安定し, 土砂量の増減がほとん ど見られないことなどから，北側隣接区域から逆流 する形で砂が運び込まれたと推測される.

\section{4. 沿岸漂砂量の算定}

一宮海岸の汀線変化が明らかになったことから， 次に一宮海岸における沿岸漂砂量分布について検討 した. 沿岸漂砂量の算定は, 汀線変化量に漂砂の移 動高を乗じる方法を用いた。この場合，一宮海岸で は太東岬による波の遮蔽があるために, 漂砂の移動 高は北側から太東漁港に接近するに従い小さくなる と考えられ, 漂砂の移動高を一定值と仮定すると大 きな誤差が含まれると考えられる。そこで深浅測量 データを用いてまず漂砂の移動高の推定を行い, そ れに基づいて沿岸漂砂量を算出した。

\section{（1）深浅データに基づく漂砂の移動高の推定}

漂砂の移動高を算出寸るには，2時期の深浅図を もとに縦断形を比較し, 波による地形変化の限界水 深 $\mathrm{h}_{\mathrm{C}}$ とバーム高 $\mathrm{h}_{\mathrm{R}}$ を求める必要がある. また比較期 間において有意な地形変化がないと縦断形変化を調 べることができない.このことから本研究では，一 宮海岸全体を網羅した深浅測量が行われた 2004 年と 現況の 2010 年の 2 時期の深浅図を用いて分析するこ ととした. 図-6は2004年と2010年の深浅図を示す。 これらの深浅図によれば，4号堤より北側では汀線 から-6mまでの等深線が互いに平行に延びているが，

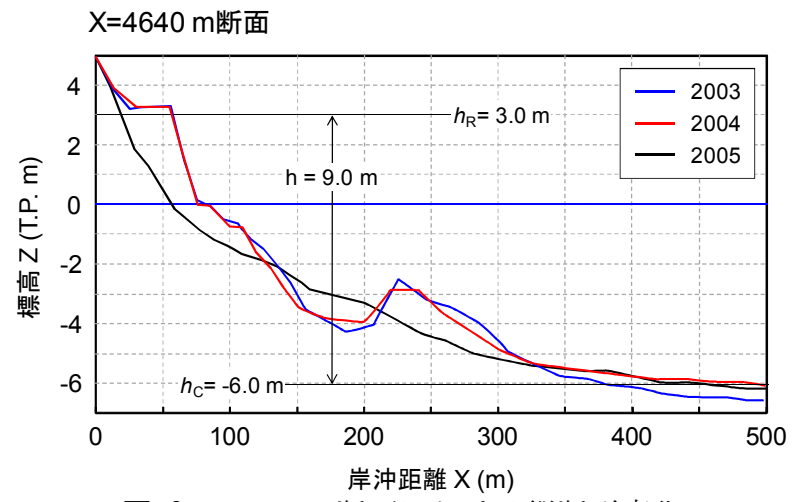

図-8 X=4.64km断面における縦断形変化

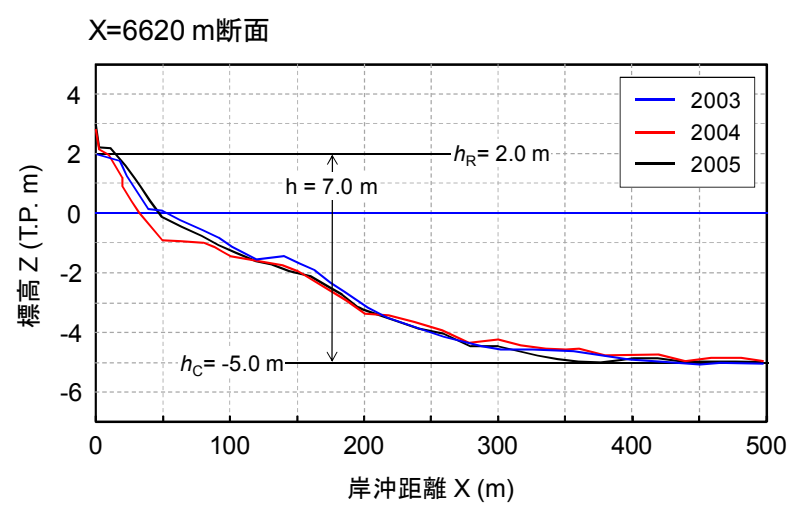

図-9 X=6. 62km断面における縦断形変化

4 号堤から太東漁港近傍では汀線と平行なのは- $4 \mathrm{~m} の$ 等深線であり, これらの水深を境に岸側と沖側の海 底勾配が急変し，岸側の海底勾配に比較して沖合で は海底勾配が小さくなり, 緩勾配に変わる。これは 太東崎による波の遮蔽効果が現れていることによる. また細かく見ると2010年の深浅図において2〜5号堤 ではHLの沖合において等深線の蛇行が起きている. 一般に防波堤が伸ばされた場合, 波の遮蔽域は通 年のエネルギー平均の方向（一宮海岸ではN $97^{\circ} \mathrm{E}$ ) 方向 ${ }^{3)}$ 基準としてそれと $45^{\circ}$ をな寸方向へと広が る. 図-7は, 図-6bに破線で示寸矩形領域を選び, 太東漁港の南防波堤の先端を通って通年のエネル ギ一平均波の方向とそれと $45^{\circ}$ をな寸方向線を引い たものであるが，ほぼ7号堤より南側が遮蔽域に入 る. そこで波の遮蔽域外から X=4.64km断面, およ び遮蔽域内から $\mathrm{X}=6.62 \mathrm{~km}$ 断面を選び，これらの断 面内での地形変化を調べた.

図-8は6号堤のすぐ南側を通るX=4. $64 \mathrm{~km}$ 断面にお ける縦断形変化を示す．6号堤は1991～1997年に縦 堤が伸ばされた。この断面では2003，2004年には バームと沖合のバーが並存する縦断形であったが, 2005年までに侵食され凹状の縦断形となった。また， 波による地形変化の限界水深はほぼ-6mにある。す なわちこの断面では $\mathrm{h}_{\mathrm{R}}=3 \mathrm{~m}, \mathrm{~h}_{\mathrm{C}}=-6 \mathrm{~m}$ となる. 同様に 図-9は, 10 号堤の南 $80 \mathrm{~m}$ に位置する $\mathrm{X}=6.62 \mathrm{~km}$ 断面の 縦断形変化を示すが，ここでは $\mathrm{h}_{\mathrm{R}}=2 \mathrm{~m}, \mathrm{~h}_{\mathrm{C}}=-5 \mathrm{~m}$ とな る. 漂砂の移動高を $\mathrm{h}_{\mathrm{R}}$ と $\mathrm{h}_{\mathrm{C}}$ の和で近似すれば，波の 遮蔽域外と遮蔽域内ではそれぞれ $9 \mathrm{~m}$ と $7 \mathrm{~m}$ とる。 


\section{（2）沿岸漂砂量分布の推定}

漂砂の移動高が与えられたことから, 南端の太東 漁港を基点として1947年基準での汀線変化から海浜 面積変化量を算出し，その上で図-10の上段に示す 漂砂の移動高を乗じ, 太東漁港から北向きに積分し た海浜土砂変化量を図-10下段に示す。これによれ ば太東漁港の防波堤が大きく伸ばされる前の1980年 ではX=5km以南で堆積が起きていたが，時間経過と ともに堆積域は北側へと広がり，2010年ではX $=2 \mathrm{~km}$ 以南が堆積域に変わった。

太東漁港の防波堤は1974年から伸ばされ，1980年 には南防波堤を除きほぼ概成していたことから，ほ ぼ1980年以降太東漁港を回り込む沿岸漂砂量は大き く減少していたと考えられる。そこで1980年以降太 東漁港を横切る沿岸漂砂量を 0 と仮定して 1990, 2000，2010年までの平均沿岸漂砂量を求めた。結果 を図-11に示す。正の沿岸漂砂量は南向きの沿岸漂 砂を表すが，3号堤より南側の区域ではいずれも太 東漁港方面への沿岸漂砂となっている。また，北向 きの沿岸漂砂は3号堤以北でのみ生じているが, そ れも近年では消失しつつある.

\section{5.まとめ}

南九十九里浜の一宮海岸では，太東崎方面から供 給される北向きの沿岸漂砂の枯渇状況に対応し, 減 少した沿岸漂砂のもとで海岸線の安定化を図ること を目的として1988年からHLの建設が進められてき た.しかしHLの建設時期と重なる時期（1981-1991 年）に太東漁港の南防波堤が建設され，これによる 波の遮蔽効果が北側海浜に及び, 波の遮蔽域の外側

（北側）から内側（南側）への沿岸漂砂が生じ，太 東漁港の近傍では著しい堆砂が生じた。沿岸漂砂の 方向は太東漁港の防波堤建設前と比較して逆転する ことになったＨＨ群の建設には長い時間を要して いるが，それらの建設期間中に当初設定された諸条 件のうち最も基本となる沿岸漂砂の方向の反転が起 きた。現在, 太東漁港では堆砂が著しいが，これに 伴って漁港の航路維持に支障を来たしており，毎年 浚渫が繰り返して行われているが十分な効果が現れ ていない。このように一宮海岸HL群は, 当初は北 向きの沿岸漂砂を阻止し海浜を防護することが目的 であったが，基本となる沿岸漂砂の向きが反転した 条件のもとでは，それらの施設の持つ意味がむしろ 漁港への沿岸漂砂の逆流を防止し, 漁港への過剰な 堆砂を防止する役目に変わったと言える。一宮海岸 のHLは侵食対策として建設に長い年月を要したが, その間にHLの建設の前提としてきた沿岸漂砂の条 件が別の目的として造られた施設（防波堤）建設に よる影響で大きく変化したのである。これと同様な

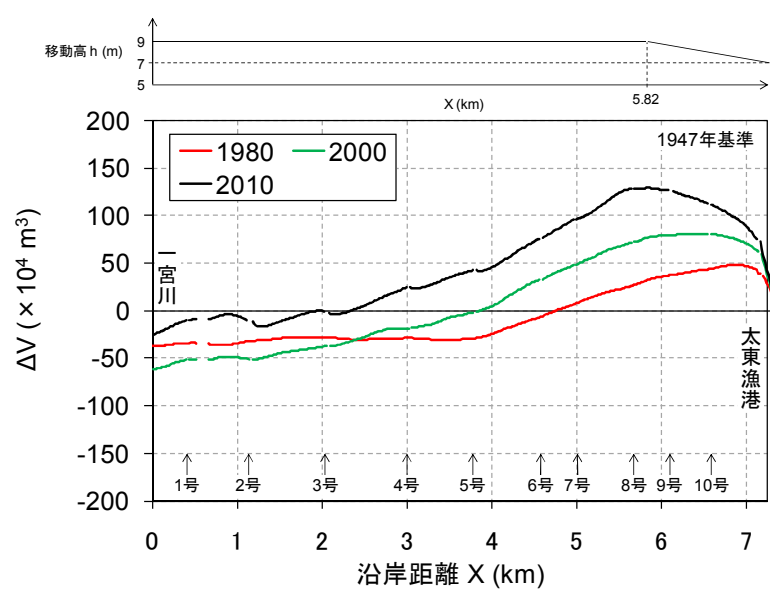

図-10 太東漁港の北側区域での堆積侵食土砂量

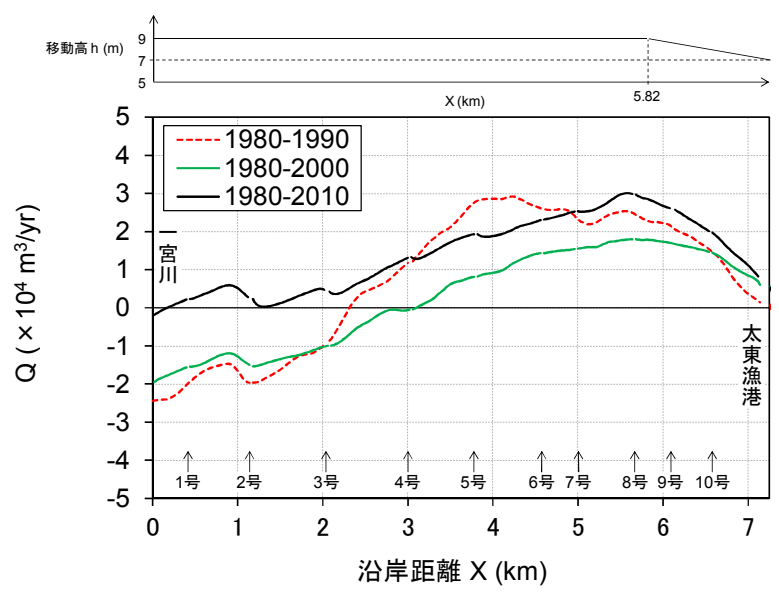

図-11 太東漁港の北側区域での沿岸漂砂量分布

状況をたどった施設は全国に数多いと考えられるが， 海岸状況のモニタリングなどを通じて海岸状況の変 化を確認し, 漂砂環境の変化に合わせて様々な改良 を加えていくことが必要と考えられる.また，一宮 海岸沖では沖合養浜 ${ }^{4)}$ も行われてきているが, 従来 その土砂は北向きの沿岸漂砂によって緩やかに拡散 すると考えられ交てきたが，上記分析結果によれば, 土砂投入箇所によっては太東漁港への逆流を促進す る可能性もあることから, 沖合養浜の場所の選定に も十分注意を払う必要があると考えられる。

\section{参考文献}

1) 宇多高明: 日本の海岸侵食, 山海堂, p. 442, 1997.

2) 宇多高明, 古池 鋼, 三波俊郎, 芹沢真澄 : 海食崖に 続く堆積性弧状海岸線の形成とその変形予測, 地形, Vol. 30, pp. 331-348, 2009.

3) 宇多高明, 古池 鋼, 星上幸良, 長山英樹 : 南九十九 里浜における侵食対策としての養浜の効果検討, 海岸 工学論文集, 第 55 巻, pp. 731-735, 2008.

4) 宇多高明, 田代洋一, 長山英樹 : ナローマルチビーム 測量による沖合養浜時の土砂移動観測, 海岸工学論文 集, 第 55 巻, pp. 776-780, 2008. 